DOC ,

D101.60/4:

1079

Technical Report 1079

\title{
Analog Scales of Affective and Continuance Commitment
}

Trueman R. Tremble, Jr.

U.S. Army Research Institute

Stephanie C. Payne

George Mason University

Consortium Research Fellows Program

R. Craig Bullis

Center for Army Leadership, Command and General Staff College

April 1998

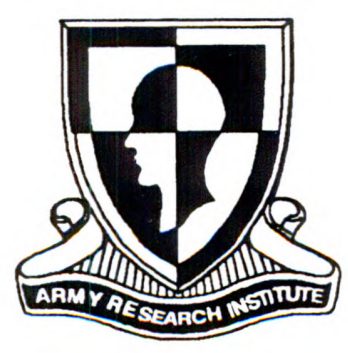

United States Army Research Institute for the Behavioral and Social Sciences

Approved for public release; distribution is unlimited. 